\title{
The Worldwide Phenomenon of Nationalism versus Globalism: A Rhetorical Perspective
}

\author{
Ben Voth', \\ bvoth@mail.smu.edu \\ 1) Associate Professor of Communication \\ and Director of Debate, Southern Methodist University.
}

\begin{abstract}
Aristotle long ago explained the definition and essential praxis of rhetoric: the faculty of observing in any given situation all available means of persuasion. 2400 years later, the global praxis of politics is being jolted by persistent bouts of nationalism that threaten a normative order of globalism evident at least since the end of World War II. In this essay, a rhetorical study of the phenomena of globalism is provided. Prominent examples of nationalism are examined with their attendant political rhetoric, with four case studies; second, consistent implications from these disparate examples and case studies form a basis for a unifying rhetorical theory of nationalism versus globalism in the 21st century. The observed characteristics of nationalist versus globalist rhetoric include: Nationalist rhetoric appeals to local interests and casts external interests as a disruptive threat; Globalist rhetoricians and sympathetic media cast their competing interests as evolutionary and progressive; Nationalist rhetoric is currently resurgent and more successful than its globalist rhetorical counterpart; and, There is not a singular globalizing narrative pulling humanity to a unipolar order. Twenty-first century rhetoric draws from these elements to form persuasive political arguments in the present era.
\end{abstract}

* Keywords: nationalism, rhetoric, globalism, argumentation, politics, Brexit, India, Nigeria. 


\section{Overview}

Initially, it is important to understand the status quo being challenged by ascendant nationalism. The global order is often described as featuring and progressing toward a notion of globalism. What does globalism mean? Globalism has at least several evident characteristics: 1) increased interdependence of nations with regard to various interests including trade and military action, 2) increased acceptance and even promotion of immigration from areas of despondency to areas of prosperity, 3) urbanization increasing while the agrarian and rural society is in decline, and 4) an increasing profession rhetorically for interstate agreements such as climate accords or the joining of states in affiliations such as the European Union. Many more characteristics could likely be added and each of these characteristics could be meaningfully subdivided into further categories, but these four certainly provide a recognizable rhetorical coherence for what is meant by terms such as globalism.

Since the end of World War II various rhetorical venues within nations often offered by major political leaders directed the world toward increasing processes of globalism. Aristotle provides the original idea of rhetorical study in his definition of the term: "Rhetoric is the faculty of observing in any given situation all available means of persuasion" Aristoteles (1975). As such, we are concerned with the persuasive elements involved with communication. More than that, however, rhetorical study requires an examination of communication in its contexts so we can better understand the original communication. In this this essay we will examine the argumentation surrounding globalism to gain a better understanding of the competing communication of globalism and nationalism. Free trade agreements between national pairs and increasingly trade agreements as regional pacts such as NAFTA, and now USMCA, signaled a rhetorical notion of progression. The world would reduce the risk of war and reduce the incidence of poverty by adhering to such an agenda of interoperable economies and national populations. Global commitment to this assumption is irregular and this of course adds to global conflict on the question of globalism. Russia, China, and Iran do resist this notion of cooperative economics. Profound correlations tend to support the positive results of these globalization efforts, however. Scholar Steven Pinker documents an overwhelming raft of data that points to success in reducing a range of harms from unclean water to disease and poverty. Pinker (2018) These declines are not marginal and are in fact significant. Rosling (2019) is another data researcher that offers compelling confirmation of this correlation. This evidence and so much more constitutes a substantial rhetorical basis or point of argument for the resistance to nationalism and ongoing adherence to a now established status quo of globalization.

Before trying to explain, we must now observe the ascendant nationalism. What is meant by nationalism? Nationalism must at least mean a domestic internal preference for the interests of those citizens within a nation. More decidedly nationalism today tends to mean that the broad forces of multiculturalism and exchange threaten traditional norms of a national society that warrant an evident political defense. Local community members are defending their traditions with public arguments and this constitutes the key basis of our current study. Nationalism responds to threats from outside the nation. Globalists will tend to describe these threats as "perceived." Herein lies an important rhetorical dialectic over which globalists and nationalists struggle. What is a real threat? Is immigration a threat? Is free trade a threat? Is global warming a threat? All of this establishes effective basis while not exhausting the topic - of what nationalism is and how we might recognize it rhetorically when we observe it as Aristotle suggests.

Specific examples of ascendant nationalism arguably include the election of various leaders from countries around the world: Donald Trump, United States; Narendra Modi, 
India; Boris Johnson, Britain; Scott Morrison, Australia; Andrzej Duda, Poland; Vladimir Putin, Russia; and Muhammadu Buhari, Nigeria. The issue is much more granular than the election of national leaders. Within this vast political sphere and dialectic of globalism versus nationalism are competing issues of trade, immigration, and interstate compacts. The controversy over Britain's exit from the European Union is rooted in a referendum of the British public that shocked international observers who encountered that public willing to tear up one of the most significant international agreements on the planet: the European Union. The long struggle to accomplish that public will of leaving the EU failed at the hands of Teresa May and the sensational nature of this public unrest has its own salient term: "Brexit." The rhetorical salience is apparent in the viral nature of the name that is appropriated to describe any number of local populace disruptions of consensus. "Calexit," for example, is a term describing the possible break up or exit of California from the United States. Brexit is absolutely a European signifier, meaning that its ultimate success could possibly lead to the complete dissolution of the European Union. These examples are not only economic. Moral issues can also serve as a point of rhetorical and argumentation struggle globally. In the United States, for instance, a seemingly mundane vote about gay marriage and Methodist unity was shattered over the independent voices of African Methodist delegates who would not be dominated by their established white counterparts on such a contentious theological point. Their localism disrupted a globalist trend toward greater sexual permissiveness that seemed assured as a pattern. The phenomenon is not limited to conventional western powers, however. In the examples that will follow, we review the communication and contexts of Brexit, Australian nationalism, Hindu nationalism, and Nigerian nationalism.

\section{Brexit Case Study}

Britain's effort to remove itself from the EU is an iconic case study in nationalism rhetoric. Observe this sensational description of events from September 2019:

Jeremy Corbyn and the other leaders of the "Rebel Alliance" today agreed to work together to stop Boris Johnson forcing an early general election on Monday as the chances of a Brexit delay increased.

Labour, the SNP, the Liberal Democrats, the Greens and Plaid Cymru will either vote against the government or abstain when Mr. Johnson holds a crunch vote at the start of next week in a bid to go to the country on October 15.

The Prime Minister will need the support of two thirds of the House of Commons to succeed but with the opposition now all on the same page his attempt at triggering a snap poll appears doomed to failure.

That could leave the PM stuck in Number 10 but unable to deliver a No Deal Brexit on October 31 and he could be forced to resign rather than break his "do or die" pledge.

Mr. Johnson today declined to rule out resigning if he fails to deliver Brexit by the current deadline as he embarked on a visit to Scotland.

He said: "That is not a hypothesis I'm willing to contemplate. I want us to get this thing done" (Maidment, 2019). 
The terminology of "Rebel Alliance" is a clear allusion to the Star Wars Film trilogy and rhetorically casts those defending the status quo of globalism as insurgent rebels fighting off the likes of Darth Vader and various supporters of Brexit such as Boris Johnson. This is rather ironic since the EU is the normative status quo and the rebellion is clearly a populist insurgency that opposes that status quo and seeks and exit from the EU grand alliance.

\section{Australia Case Study}

Slate magazine provides another provocative rhetorical framing of the nationalist insurgency in Australia. With the provocative headline--"What the Bloody Hell Just Happened in Australia? A shocking election upset has confused Australians searching for answersSlate proceeded to describe in blunt terms the inconceivable Australian backlash against globalism:

The polls were wrong. The pundits were wrong. The party insiders were wrong. The bookies were wrong. I was wrong. Even Burt the psychic croc was wrong.

Australia's dysfunctional, unpopular, conservative government (the Liberal and National parties, currently in coalition, sit on the right in Australian politics) held onto power for a third term in Saturday's national election. This happened despite the fact that most analysts expected it to lose a large number of seats; despite being (seemingly) out of step with the nation's emerging consensus on climate change, marriage equality, religion, and race; despite a chaotic tenure in office that has seen three leaders since 2016; despite a threadbare policy agenda; despite many of its high-profile figures recently retiring in frustration or anticipation of defeat; despite betting agencies paying out Labor backers early; despite losing more than 50 consecutive opinion polls. After all of it, the conservatives won the only poll that mattered, in what reelected Prime Minister Scott Morrison, an evangelical Christian, called "a miracle" Withers (2019).

Slate provides a rhetorical framing of shocked indignation- not unlike the election of President Trump in November 2016. Progressive issues such as gay marriage and climate change form key aspects of some sense of political inevitability envisioned by the Slate magazine. Scott Morrison was re-elected to the government of Australia and it appears again that there is a hidden bloc of voters unseen by major media at work down under. Moreover, in reading this article the reactionary stance of the writer toward Christians is evident and directed at the identity of the elected "evangelical" leader of Australia. Christianity is a long 2,000-year tradition of religion, ethics, and politics (Millenia longer if the "Judeo" part of the JudeoChristian tradition is considered). Slate editorial anger that this Christian leader could be reelected challenged their notion of "progress." There is a clear sense of epistemic collapse. The normal order of explanation is no longer functional (Withers, 2019).

\section{Hindu Nationalism in India}

India is on track to becoming the most populous nation in the world by the middle of the 21st century. This nation recently experienced a resurgence of nationalism in its affinity for the Hindu national party of the BJP. This media example provides an indication of the 
populist popularity of Prime Minister Modi:

On a hot day in May, Indian Prime Minister Narendra Modi held a campaign rally in the central Indian city of Indore. Young men spread as far as the eye could see. Wearing bright orange T-shirts that said "NAMO AGAIN!" in comic-book letters, they scanned the sky for the helicopter carrying their superhero, the soon-to-be-reelected prime minster.

Patriotic songs from major Bollywood war hits played in the background. A particular favorite, from the film Border, was sung in the film by homesick soldiers on the battlefront, remembering the mothers and sweethearts who waited for them at home. The song was apt for what had become a nationalsecurity election, fought in the shadow of air strikes against Pakistan. The young men at the rally were soldiers, too, of a sort-soldiers for the cause of a Hindu nation (Chandra, 2019).

The synthetic nature of nationalism was apparent in a recent rally in Houston, Texas, featuring Modi and Trump (Kapur, 2019). Both men worked together to encourage mutual support among Indians for the two leaders. The two men are raising their internal legitimacies by appealing to notions of nationalism. India is an important global example since they make up such a huge portion of the global population and a rising force in the global economy. The political rivalries of India with Pakistan and China make the nation a strategic partner for the United States that increasingly seeks to contain both Pakistan and China as threats to American interests.

\section{Nigerian Nationalism}

Nigeria's emergence as the leading economy on the continent of Africa has not made it immune from the struggle between globalism and nationalism. South Africa was the former largest economy and a sense of rivalry is evident in this media sample from BET entitled, "Nigerian Youth Coalition Warns South African Investors To Leave Nigeria":

The nationalist youth group issued a seven-day ultimatum, threatening to attack South African investors with thriving businesses throughout Nigeria.

Amid widespread reports alleging Nigerian immigrants are under fatal xenophobic attacks in South Africa, Sahara Reporters announced . . . that the Oodua Youth Coalition issued a seven-day ultimatum to all South African business owners and investors in Nigeria, warning them "to leave the country or risk being attacked." The announcement follows reports saying Nigerians and their businesses in South Africa are under brutal attack.

"Oodua Youth Coalition is saddened and angered that South Africans, supported by the country's authorities, is coordinating the looting and burning of Nigerian businesses and maiming and killing of our brothers and fathers in their land," said President of the OYC, Oluyi Tayo, in a statement" (Estevez, 2019). 
Nigeria is now the largest economy on the African continent. Since surpassing South Africa, the sense of rivalry between the former economic powerhouse and the new leader is evident in this immigration struggle with reciprocal violence against businesses of each nation. Leaders can rhetorically appeal to notions of nativism. Immigrants are not positively viewed, and a preference for accomplished integration is necessary for stable internal economic activity. Both nations are threatening immigrants from the other country in their economic rivalry.

\section{A 2020 view of essential characteristics of global nationalist rhetoric}

From these case studies we can derive a number of common characteristics. These consistent trends and characteristics may make us more adept at understanding ongoing 21st century rhetoric on these and related questions as they continue to emerge. The observed characteristics of nationalist versus globalist rhetoric include:

1. Nationalist rhetoric appeals to local interests and casts external interests as a disruptive threat.

2. Globalist rhetoricians and sympathetic media cast their competing interests as evolutionary and progressive.

3. Nationalist rhetoric is resurgent and more successful than its globalist rhetorical counterpart.

4. There is not a singular globalizing narrative pulling humanity to a unipolar order.

These characteristics can help us recognize future instances of such rhetoric and help us understand current communication struggles surrounding globalism. Globalism does appear to be in decline and there are many more examples that could be chosen to illustrate these points including Russia, Poland, Japan, and more. These examples examined are good representations across the world as a political stage and involves the lives of almost two billion people.

\section{Summarizing Thoughts}

Examining four major global examples of nationalist rhetoric provide a rhetorical framework for our ongoing dialectic between arguments for globalism and arguments for localism expressed as nationalism. The evidence suggests that nationalism is ascendant and that globalism is in decline as a rhetorical feature in public arguments. The natural human craving for simple explanations such as the globalizing and integrating societies may cause us to misread current events. A variety of local narratives are at work and deference to those local narratives appears to be on the rise rhetorically. It is possible that cosmopolitan integrationist impulses operate on a cyclical basis. Human societies may integrate to various outsider points of view and then recoil to consolidate and maintain tradition.

This pendulum swing between nationalism and globalism may point to our present 2020 world of ascendant nationalism as local communities affected by record global levels of immigration and economic integration draw on rhetorical traditions and patterns to re-assert their role in human affairs. It is possible that the ascendancy of nationalism may come to an end in the future but the current dominant rhetorical pattern is nationalist appeals, and 
this pattern has clear recognizable rhetorical patterns discerned in our examples. President Trump's September 2019 remarks to the United Nations about a future bound by patriots signals the bold trend discovered in this analysis. The situation of these remarks was within the halls of an institution dedicated to ideals of globalism. The irony of this statement is a good summation of the global human condition oriented toward nationalism and less globalism.

\section{References}

Aristoteles (1975). Aristotle in twenty-three volumes. 22, The "art" of rhetoric. Cambridge, MA: Harvard University Press.

Estevez, M. (2019). Nigerian youth coalition warns South African investors to leave Nigeria, The Nationalist youth group issued a seven-day ultimatum, threatening to attack South African investors with thriving businesses throughout Nigeria. BET, September 9. Retrieved from https://www.bet.com/news/national/2019/09/03/xenophobia-nigerianswarn-south-africans-leave-country.html.

Kanchan, C. (2019). How Hindu nationalism went mainstream and what that means for Narendra Modi's Bharatiya Janata party. Foreign Policy, June 13. Retrieved from https:// foreignpolicy.com/author/kanchan-chandra/.

Kapur, D. (2019). The Indian prime minister and Trump addressed A Houston rally. Who was signaling what?. The Washington Post, September 9. Retrieved from https://www. washingtonpost.com/politics/2019/09/29/prime-minister-modi-india-donald-trumpaddressed-huge-houston-rally-who-was-signaling-what/.

Maidment, J. (2019). Boris Johnson loses Control: Jeremy Corbyn's rebel alliance agrees deal to block election. Daily Mail, September 6. Retrieved from https://www.dailymail. co.uk/news/article-7435249/Jeremy-Corbyns-rebel-alliance-AGREES-deal-blockelection-week-delay-Brexit.html

Pinker, S. (2018). Enlightenment now: The case for reason, science, humanism, and progress. New York, NY: Penguin Books.

Rosling, R. (2019). Hans Rosling's 200 Countries, 200 Years, 4 Minutes - The Joy of Stats BBC Four. Retrieved from https://www.youtube.com/watch?v=jbkSRLYSojo.

Withers, R. (2019). What the Bloody Hell Just Happened In Australia? A shocking election upset has confused Australians searching for answers. Slate, May 20. Retrieved from https://slate.com/news-and-politics/2019/05/australia-election-upset-scott-morrison. $\underline{\text { html }}$

This article is distributed under the terms of the Creative Commons Attribution 4.0 License (https://creativecommons. org/licenses/by/4.0/) which permits any use, reproduction and distribution of the work without further permission provided the original work is attributed as specified on the WCSA Journal by World Complexity Science Academy (https://wcsajournal.com/wcsaj-legal-statement/). 
